WPS3795

\title{
A More Complete Conceptual Framework for Financing of Small and Medium Enterprises
}

\author{
Allen N. Berger \\ Board of Governors of the Federal Reserve System, Washington, DC 20551 U.S.A. \\ Wharton Financial Institutions Center, Philadelphia, PA 19104 U.S.A. \\ aberger@frb.gov \\ Gregory F. Udell \\ Kelley School of Business, Indiana University, Bloomington, IN 47405 U.S.A. \\ gudell@indiana.edu
}

\begin{abstract}
We propose a more complete conceptual framework for analysis of credit availability for small and medium enterprises (SMEs). In this framework, lending technologies are the key conduit through which government policies and national financial structures affect credit availability. We emphasize a causal chain from policy to financial structures, which affect the feasibility and profitability of different lending technologies. These technologies, in turn, have important effects on SME credit availability. Financial structures include the presence of different financial institution types and the conditions under which they operate. Lending technologies include several transactions technologies plus relationship lending. We argue that the framework implicit in most of the literature is oversimplified, neglects key elements of the chain, and often yields misleading conclusions. A common oversimplification is the treatment of transactions technologies as a homogeneous group, unsuitable for serving informationally opaque SMEs, and a frequent misleading conclusion is that large institutions are disadvantaged in lending to opaque SMEs.
\end{abstract}

JEL Classification Numbers: G21, G28, G34, L11, F33

Key words: SMEs, Banks, Relationship Lending, Governance, International.

World Bank Policy Research Working Paper 3795, December 2005

The Policy Research Working Paper Series disseminates the findings of work in progress to encourage the exchange of ideas about development issues. An objective of the series is to get the findings out quickly, even if the presentations are less than fully polished. The papers carry the names of the authors and should be cited accordingly. The findings, interpretations, and conclusions expressed in this paper are entirely those of the authors. They do not necessarily represent the view of the World Bank, its Executive Directors, or the countries they represent. Policy Research Working Papers are available online at http://econ.worldbank.org.

The authors thank the anonymous referees, Zoltan Acs, Thorsten Beck, Lamont Black, Cesare Calari, Asli Demirguc-Kunt, Scott Frame, and Leora Klapper for valuable direction with the paper, and participants in the World Bank Conference on "Small and Medium Enterprises: Overcoming Growth Constraints" and the Australasian Finance and Banking Conference for helpful discussion.

Please address correspondence to Allen N. Berger, Mail Stop 153, Federal Reserve Board, 20th and C Streets. NW, Washington, DC 20551, call 202-452-2903, fax 202-452-5295, or email aberger@frb.gov. 


\section{WPS3795}

\section{Introduction}

The availability of external finance for small and medium enterprises (SMEs) is a topic of significant research interest to academics and an important issue to policy makers around the globe. The conceptual framework to which most of the current research literature adheres has been quite helpful in understanding the institutions and markets that provide funds to SMEs in developed and developing nations. This framework has also provided insights into the effects of policies that affect access to funding by creditworthy SMEs in

these nations. However, we argue that the current framework is oversimplified, and neglects key elements of the financial system that affect SME credit availability.

We propose a more complete framework in which lending technologies play a key role as the conduit through which government policies and national financial structures affect SME credit availability. We define a lending technology as a unique combination of primary information source, screening and underwriting policies/procedures, loan contract structure, and monitoring strategies/mechanisms.

An important oversimplification in the current framework is the way that lending technologies are often categorized into two types: transactions lending that is based primarily on "hard" quantitative data and relationship lending, which is based significantly on "soft” qualitative information. Under this categorization, transactions lending is generally viewed as being focused on informationally transparent borrowers, while relationship lending is seen as used for opaque borrowers.

In our view, this characterization is fundamentally flawed. Transactions lending is not a single homogeneous lending technology. There are a number of distinct transactions technologies used by financial institutions, including financial statement lending, small business credit scoring, asset-based lending, factoring, fixed-asset lending, and leasing. While financial statement lending is focused on transparent borrowers, these other transactions technologies are all targeted to opaque borrowers. Recognition of this heterogeneity among transactions technologies and its impact on credit availability to opaque borrowers is often missing from the academic literature.

Our framework specifies a causal chain from government policies to a nation’s financial institution structure and lending infrastructure. These financial structures, in turn, significantly affect the availability of funds to SMEs by determining the feasibility and profitability with which different lending technologies may be deployed. Financial institution structure refers to the market presence of and competition among different 


\section{WPS3795}

types of financial institutions and lending infrastructure refers to the rules and conditions that affect the ability of these institutions to lend. The extant research literature often neglects key elements of this causal chain, which may yield misleading research and policy conclusions.

To illustrate, consider the recent research on financial institution size, one dimension of financial institution structure. A common finding is that large institutions have a comparative advantage in transactions lending to SMEs based on hard information, while small institutions have a comparative advantage in relationship lending based on soft information. A policy implication that might at first blush seem reasonable is that the financial institution structure must include a substantial market share for small institutions to meet the demands of informationally opaque SMEs, since large institutions rely on hard information for their transactions lending technologies.

While the current conceptual framework is likely correct in associating large institutions with transactions technologies, the inference that large institutions are disadvantaged in lending to opaque SMEs is flawed. Large institutions deliver credit to many types of opaque SMEs through the transactions lending technologies that specifically address problems of informational opacity using hard information. For small business credit scoring, large institutions use hard information on the SME and/or its owner obtained from credit bureaus to infer future loan performance; for asset-based lending, these institutions use valuations of the assets pledged as collateral to evaluate repayment prospects; for factoring, they focus on the quality of the accounts receivable purchased; for fixed-asset lending and leasing, large institutions look to the valuations of the fixed assets that are pledged as collateral (fixed-asset lending) or directly owned by the institution (leasing). Thus, when informative financial statements are not available, institutions are often able to use other types of hard information to assess repayment prospects. Similar arguments apply to potentially misleading conclusions based on the current framework about other dimensions of a nation's financial structures and the policies that affect these structures.

Research on SME finance suffers from the problem that the lending technologies are usually not identified. This makes it difficult to test theories that relate financial structures to credit availability for different types of borrowers and to make policy assessments of which financial structures function best in supplying funds to creditworthy transparent and opaque SMEs. The limited findings from studies that identify lending technologies suggest that significant variation in the deployment of these technologies exists 


\section{WPS3795}

across nations - an institutional fact that is not explained by the current conceptual framework. For example, asset-based lending has a significant presence in only 4 nations, Australia, Canada, the U.K., and the U.S. A goal for our framework is to try to explain a significant portion of the variation in the use of lending technologies with differences in national financial structures.

The effects of a nation's lending infrastructure on SME credit availability through determining the feasibility and profitability of deploying the different lending technologies is particularly under-researched in the literature. This infrastructure includes the information environment, the legal, judicial, and bankruptcy environments, the social environment, and the tax and regulatory environments in which financial institutions operate in a given nation. Lending infrastructures are quite heterogeneous across nations. We show how a nation's lending infrastructure affects the extent to which each of the individual lending technologies are employed in financing SMEs.

Section 2 briefly discusses each of the major lending technologies used for SMEs. Sections 3 and 4 focus on the financial institution structures and lending infrastructures of nations, respectively. We show how these structures may influence SME lending credit availability through affecting the feasibility and profitability with which the different lending technologies may be deployed. Section 5 provides some brief conclusions.

\section{Lending technologies}

We briefly define and describe each of the lending technologies, highlight its distinguishing features, and show how the technology addresses the opacity problem. Each technology is distinguished by a unique combination of the primary source of information, screening and underwriting policies/procedures, structure of the loan contracts, and monitoring strategies and mechanisms. In some cases, the technologies basically differ from one another in just one of these dimensions (e.g., fixed-asset lending and leasing primarily differ from each other on the contracting dimension - specifically, the ownership of the fixed assets). In other cases, lending technologies differ in multiple dimensions (e.g., small business credit scoring and asset-based lending differ in primary information sources and monitoring mechanisms).

In many cases, a secondary information source, screening/underwriting procedure, contract feature, or monitoring mechanism is used, but we distinguish the technologies based on the primary foundations of the lending decisions. Thus, a credit score may be used as secondary information or collateral may be used as a 
secondary source of repayment, but the lending technology would still be relationship lending if the lending decisions are primarily based on soft information gathered over the course of a relationship. ${ }^{1}$

\section{A. Financial Statement Lending}

Financial statement lending is a transactions technology based primarily on the strength of a borrower's financial statements. There are two requirements for this technology that depend on hard information. First, the borrower must have informative financial statements, such as audited statements prepared by reputable accounting firms according to widely accepted accounting standards such as GAAP. Second, the borrower must have a strong financial condition as reflected in the financial ratios calculated from these statements. The loan contract that arises out of the analysis of these financial statements may reflect a variety of different contracting elements such as collateral and personal guarantees. However, under financial statement lending, the lender views the expected future cash flow of the SME as the primary source of repayment. Financial statement lending, unlike other lending technologies, is reserved for relatively informationally transparent firms.

\section{B. Small Business Credit Scoring}

Small business credit scoring is a transactions technology based primarily on hard information about the SME's owner as well as the firm. The owner information is primarily personal consumer data obtained from consumer credit bureaus. This is combined with data on the SME collected by the financial institution and often from commercial credit bureaus. The data are entered into a loan performance prediction model, which yields a score, or summary statistic for the loan. The models are usually designed for credits up to $\$ 250,000$, but many institutions use them only for credits up to $\$ 100,000$. The technology is relatively new it was not widely used in the U.S. until the mid-1990s.

This technology may be applied to very opaque SMEs, given that much of the information is based on the personal history of the owner, rather than the SME. Consistent with this opacity, recent research finds that this technology is associated with credits under $\$ 100,000$ that are rated as relatively risky, have high interest rates, and are often located outside of the banks’ local markets (Frame, Padhi, and Woosley 2004,

\footnotetext{
${ }^{1}$ In some cases, the technologies may be most efficiently deployed in a particular organizational form or unit that is dedicated to that technology. The unit may be an entire financial institution (e.g., a leasing company offering only business leases), or a separate department, division, or subsidiary (e.g., asset-based lending department of a commercial bank or finance company).
} 
Berger, Frame, and Miller 2005). ${ }^{2}$

\section{Asset-Based Lending}

Asset-based lending is a transactions lending technology in which financial institutions address the opacity problem by focusing on a subset of the firm's assets, which are pledged as collateral, as the primary source of repayment. This technology provides working capital financing secured primarily by accounts receivable and inventory. ${ }^{3}$ The amount of credit extended is linked on a formula basis using hard data to a dynamically-managed estimation of the liquidation value of the assets used as collateral. The value of collateral is assessed daily in the case of accounts receivable, and typically weekly or monthly for inventory, and linked to the size of the credit available, so that the liquidation value of the collateral always exceeds the credit exposure (Udell 2004). ${ }^{4}$

The use of collateral itself, however, does not distinguish asset-based lending from the other lending technologies. The pledging of accounts receivable and inventory is often associated with financial statement lending, relationship lending, and credit scoring, where collateral is used a secondary source of repayment. Under asset-based lending, in contrast, the extension of credit is primarily based on the value of the collateral, rather than the overall creditworthiness of the firm.

\section{Factoring}

Factoring involves the purchase of accounts receivable by a "lender" known as a factor. As in assetbased lending, factoring focuses on the value of an underlying asset, rather than the overall value/risk of the firm. Factoring is similar to asset-based lending, but there are three important distinctions. First, factoring only involves the financing of accounts receivable, unlike asset-based lending which also involves financing inventory. Second, under factoring, the underlying asset is sold to the "lender.” Third, factoring is essentially

\footnotetext{
${ }^{2}$ See Berger and Frame (2006) for more details on small business credit scoring and its effects on credit availability.

${ }^{3}$ There is relatively little empirical evidence on asset-based finance. One study finds evidence consistent with practitioner and conventional wisdom that asset-based finance is associated with riskier borrowers (Klapper 1998). Another study of very large credits finds evidence that commercial finance company credits (which are exclusively assetbased) are riskier than commercial bank credits (which can be either asset-based or not), but did not find evidence of associating opacity with asset-based lending using standard opacity measures (Carey, Post, and Sharpe 1998).

${ }^{4}$ For the least creditworthy asset-based borrowers, lenders often establish special checking accounts into which all collections of receivables must be deposited, reducing potential diversion of these funds by the borrower (Mester, Nakamura, and Renault 2004). In addition, monitoring cash flows on deposit accounts may provide valuable hard information that may be used in conjunction with any of the lending technologies, provided that all the firms' checking accounts are consolidated at the lending institution (Nakamura 1993).
} 
a bundle of three financial services: a financing component, a credit component and a collections component. Under most factoring arrangements, the borrower outsources its credit and collections activities in addition to obtaining financing. Factoring is a transactions technology because the underwriting process based on hard information about the value of a "borrower's” accounts receivable. Factoring addresses the opacity problem by focusing primarily on the quality of the obligor, rather than the "borrower."5

The use of factoring varies widely across countries. For example, the ratio of the volume of factoring to GDP in 2002 was $11.9 \%$ in Italy, but only 0.9\% in Switzerland (Bakker, Klapper, and Udell 2004).

\section{E. Fixed-Asset Lending}

Fixed-asset lending technologies involve lending against assets that are long-lived and are not sold in the normal course of business (e.g., equipment, motor vehicles, or real estate) ${ }^{6}$ Like asset-based lending which is based on accounts receivable and inventory - the underlying assets in fixed-asset lending are pledged to the lender as collateral. However, unlike accounts receivable and inventory, the pledged assets are virtually always uniquely identified by a serial number or a deed. The long life and unique identification of fixed assets leads to very different underwriting processes, contract structures, and monitoring mechanisms. At the underwriting stage, the focus is on assessing the market value of the asset - for equipment and real estate, this is often in the form of a formal appraisal. The contract structure typically specifies an initial loan-to-value ratio less than one. It also typically involves setting a loan amortization schedule with a final maturity less than the lifespan of the asset. The schedule insures that the ratio of the outstanding loan balance to the liquidation value of the asset is less than one over the life of the loan. This contract structure also feeds back to the underwriting process, where the primary financial analysis focuses on coverage ratios that measure a firm's ability to meet the amortization schedule (i.e., debt service). ${ }^{7}$ Unlike monitoring asset-based loans, the existence of collateral (i.e., ownership of collateral by the borrower) is not problematic in fixed-asset lending.

The borrower can only sell a fixed asset by transfer of title, which can only occur if the lender agrees to

\footnotetext{
5 "Reverse factoring" is a recent innovation that has been applied in developing economies. Under reverse factoring, a factor enters into an agreement with a large company (e.g., Wal-Mart) that is purchasing goods from a large number of small suppliers. The factor agrees to finance any of the receivables of this large company generated by invoices from these small suppliers. Reverse factoring differs from conventional factoring in that the primary business arrangement is between the seller of the goods and the factor, as opposed to the supplier of the goods and the factor (Klapper 2005). ${ }^{6}$ In SME lending, fixed-asset lending can be associated with personal assets provided by the firm's owner as well as the firm's assets. A common example is an entrepreneur pledging a personal residence as collateral for a business loan.

${ }^{7}$ Coverage ratios are calculated by dividing a measure of cash flow by a measure of debt service.
} 


\section{WPS3795}

release the lien. Monitoring the borrower's ability to pay (i.e., its cash flow) is tied to the observation of timely repayment as specified by the amortization schedule. Failure to meet a required payment signals inadequate cash flow and triggers a default on the loan.

\section{F. Leasing}

Leasing involves the purchase of fixed assets by a "lender" known as a lessor. Leasing is a very common method of financing equipment, motor vehicles, and real estate in many countries by both banks and other institutions. The lessor purchases the fixed assets and then simultaneously enters into a rental contract with the lessee (the "borrower") that specifies the payment schedule. The contract often contains an option whereby the lessee can purchase the assets at the end of the lease at a pre-specified price.

Leasing is a transactions technology because underwriting is substantially based on hard information about the value of the underlying asset, analogous to asset-based lending, factoring, and fixed-asset lending. Like these other technologies, leasing can be used to provide financing to opaque firms because the underwriting decision is primarily based on the value of the asset being leased. It has also been shown that leasing can mitigate an adverse selection problem, either in the used equipment market by encouraging a higher quality of product sold "off-lease" (i.e., sold by lessors when the purchase option is not exercised) or in the new product market (Chemmanur and Yan 2000, Hendel and Lizzeri 2002, Gilligan 2004). ${ }^{8}$

\section{G. Relationship Lending}

Under relationship lending, the financial institution relies primarily on soft information gathered through contact over time with the SME, its owner and the local community to address the opacity problem. This information is acquired in large part by the loan officer through direct contact with the borrower and through observing the SME's performance on all dimensions of its banking relationship. This soft information may also include an assessment of the future prospects of the SME garnered from past communications with SME’s suppliers, customers, or neighboring businesses (Petersen and Rajan 1994, Berger and Udell 1995, Degryse and van Cayseele 2000). As noted, this soft information may often remain proprietary to the loan officer because it is not easily observed, verified, or transmitted to others.

\footnotetext{
${ }^{8}$ Leasing may also provide for an optimal sharing of tax benefits when there is a differential tax rate between the lessor and the lessee (e.g., Graham, Lemmon, and Schallheim 1998).
} 


\section{WPS3795}

\section{H. Trade Credit}

The importance of trade credit to SME financing is a compelling reason to include it as a lending technology, although it is not delivered by financial institutions. Trade credit represented one-third of the debt of U.S. SMEs as of 1998, nearly that extended by commercial banks (Robb 2002). Trade credit may be particularly important in economies with weak financial systems, where industries with higher dependence on trade credit exhibit higher growth rates (Demirguc-Kunt and Maksimovic 2002, Fisman and Love 2003).

It is not straightforward to classify trade credit as either a transactions based or a relationship based technology. Many of the procedures and processes associated with the other lending technologies are used in underwriting trade credit. For example, credit scoring and similar quantitative techniques have long been a part of the underwriting process used by credit managers. For larger accounts, financial statements are analyzed as part of the underwriting process. However, soft information and mutual trust play a role in some trade credit underwriting, similar to relationship lending.

Researchers have suggested comparative advantages for product sellers in funding, production/inventory management, price discrimination, or product quality guarantees. Some have also suggested that suppliers may have an informational advantage over other lenders in evaluating their customers' ability to pay, solving incentive problems effectively, repossessing and reselling goods in the event of default, or withholding future supplies (see Petersen and Rajan 1997 for a summary of this research). More recent evidence suggests additional advantages of trade credit. These include a signaling role in developing economies, reduced incentive to strategically default, an informational advantage in lending to less creditworthy firms when trade creditors are given a security interest, and an advantage in financing nonstandardized products (Cook 1999, Cunat 2003, Frank and Maksimovic 2003, Burkart and Ellingsen 2004, Burkart, Ellingsen, and Giannetti 2005, Chan, Chan, Jegadeesh, and Lakonishok 2006).

\section{Financial institution structure}

In this section, we focus on the effects of a nation's financial institution structure on the feasibility and profitability with which the different lending technologies can be deployed to fund SMEs. The research literature provides a considerable amount of evidence on the effects of financial institution structure on SME lending, but the findings rarely go beyond the distinction between transactions lending technologies versus relationship lending to parse among the different transactions technologies. We briefly review the findings 


\section{WPS3795}

with regard to the comparative advantages of large versus small institutions, foreign- versus domesticallyowned institutions, state- versus privately-owned institutions, and market competition.

\section{A. Large versus small institutions}

For a number of reasons, large institutions may have a comparative advantage in transactions lending and small institutions may have an advantage in relationship lending. Large institutions may be able to take advantage of economies of scale in the processing of hard information, but be relatively poor at processing soft information because it is difficult to quantify and transmit through the communication channels of large organizations (e.g., Stein 2002). Under relationship lending, there may be agency problems created within the financial institution because the loan officer that has direct contact over time with the SME is the repository of soft information that cannot be easily communicated within the financial institution. This may give a comparative advantage in relationship lending to small institutions with fewer layers of management (e.g., Berger and Udell 2002). Finally, large institutions may be disadvantaged at relationship lending because of Williamson-type (Williamson 1988) organizational diseconomies associated with also providing transactions loans and other wholesale services.

The empirical literature generally does not identify the lending technologies, but in some cases draws conclusions from the characteristics of the SME borrowers and their relationships with financial institutions. In most cases, the research is based on data from U.S. banks and SMEs. Large institutions are found to lend to larger, older SMEs with stronger financial ratios, and small institutions are found to rely more on soft information and lend to SMEs with which they have stronger relationships (e.g., Haynes, Ou, and Berney 1999, Cole, Goldberg, and White 2004, Scott 2004, Berger, Miller, Petersen, Rajan, and Stein 2005). The strong financial ratios and SME size and age findings are consistent with a comparative advantage for large institutions in using financial statement lending based on financial ratios for relatively transparent SMEs (which tend to be larger and older), given that financial statement lending is the only lending technology generally used for transparent borrowers. The strong relationships and use of soft information by small institutions is consistent with a comparative advantage for small institutions in relationship lending. There is very little evidence on comparative advantages by financial institution size in the other transactions lending technologies, although it is likely that large institutions have comparative advantages of differing degrees in the other transactions technologies due to economies of scale in processing hard information. 


\section{WPS3795}

A limited amount of empirical evidence also addresses the issue of a general comparative advantage of large versus small institutions in SME lending and the policy question of whether a sizeable presence of small institutions is necessary to promote credit availability for SMEs. One study finds that the likelihood that an SME has a line of credit from a large bank versus a small bank is roughly proportional to the deposit market presence of large versus small banks (Berger, Rosen, and Udell forthcoming). This is not consistent with a general comparative advantage by financial institutions size and suggests that a strong presence of small institutions may not be needed for general SME credit availability. This study also found few significant differences in the opacity or other characteristics of small businesses that borrow from large versus small banks. These two findings are consistent with the hypothesis that large institutions using various transactions technologies are just as able to supply SME credit to opaque SMEs as small institutions using relationship lending.

Another study found that the local market shares of large and small U.S. banks have relatively little association with SME credit availability, but did not account for the size of institutions making the loans (Jayaratne and Wolken 1999). This study is also consistent with the hypothesis that large institutions are not disadvantaged in SME lending and that a strong presence of small institutions may not be needed for general SME credit availability. An alternative hypothesis to explain this finding is that large institutions may be generally disadvantaged at SME lending, but that a sufficient market presence of small institutions efficiently arises endogenously when needed to provide adequate SME credit. Supporting this second hypothesis, several studies find that large institutions reduce their SME lending after mergers and acquisitions, but that other banks in the same local markets appear to respond by increasing their supply of SME credit substantially (e.g., Berger, Saunders, Scalise, and Udell 1998, Berger, Goldberg, and White 2001, Avery and Samolyk 2004). As well, new small banks are often created in these markets that supply additional SME credit (Berger, Bonime, Goldberg, and White 2004).

Thus, the research suggests that concern about the policy issue of whether a sizeable presence of small institutions is needed for SME credit availability in U.S. markets may not be warranted. However, these findings may not apply to other nations because of differences in financial institution structure and lending infrastructure that may limit the use of some of the lending technologies. In an international comparison, greater market shares for small banks are associated with higher SME employment and more 


\section{WPS3795}

overall bank lending in both developed and developing nations (Berger, Hasan, and Klapper 2004).

\section{B. Foreign-owned versus domestically-owned institutions}

Foreign-owned institutions may have a comparative advantage in transactions lending and a disadvantage in relationship lending in part because these institutions are typically large. In developing nations, foreign institutions headquartered in developed nations may have an additional advantage in transactions lending because of access to better information technologies for collecting and assessing hard information. ${ }^{9}$ Foreign institutions may also face additional hurdles in relationship lending because of difficulties in processing and transmitting soft information over greater distances, through more managerial layers, and coping with multiple economic, cultural, language, and regulatory environments (e.g., Buch 2003).

There is little empirical evidence on SME lending by foreign-owned institutions in developed nations. Some research finds that these institutions tend to have a wholesale orientation (e.g., DeYoung and Nolle 1996), and in some cases tend to specialize in serving multinational corporations headquartered in their home nation (e.g., Goldberg and Saunders 1981). Presumably, these institutions use transactions technologies applied to hard information.

There is more evidence on foreign-owned institutions and SME credit availability in developing nations. In most of the studies, foreign banks are associated with greater SME credit availability (e.g., Beck, Demirguc-Kunt, and Maksimovic 2004a, Berger, Hasan, and Klapper 2004, Clarke, Cull, Martinez Peria, and Sanchez 2005). However, some find that foreign-owned banks may have more difficulty in supplying credit to SMEs than to large firms (e.g., Berger, Klapper, and Udell 2001, Mian 2005). This relative preference for large firms over SMEs has also been found for foreign lenders entering formerly socialist countries (Giannetti and Ongena 2005). Again, the lending technologies are generally not identified. Although foreign institutions almost surely use transactions technologies, it is usually not known which of these technologies are employed or the opacity of the borrowers served. ${ }^{10}$

\footnotetext{
${ }^{9}$ For example, some foreign-owned institutions use a simplified form of small business credit scoring to lend to SMEs in developing nations based on the SME's industry or provide home-nation training for loan officers stationed in developing nations (Berger, Hasan, and Klapper 2004).

${ }^{10}$ There is also research on the efficiency of foreign versus domestic institutions, but the efficiency differences may or not be linked to lending technologies and SME credits. The research in developed nations suggests that foreign institutions are less efficient on average (e.g., DeYoung and Nolle 1996, Berger, DeYoung, Genay, and Udell 2000).
} 


\section{State-owned versus privately-owned institutions}

State-owned institutions may be expected to have a comparative advantage in transactions lending and a disadvantage in relationship lending because these institutions are typically large. Other arguments regarding the ability of these institutions to supply funds to creditworthy SMEs through any lending technology may also apply. State-owned institutions generally operate with government subsidies and often have mandates to supply additional credit to SMEs in general, or to those in specific industries, sectors, or regions. Although this might improve funding to creditworthy SMEs in principle, it could have the opposite effect in practice because these institutions may be inefficient due to a lack of market discipline. As well, much of their SME funding may be to SMEs that are not creditworthy because the lending mandates do not necessarily require that the funding be used to finance positive net present value projects, or that loans be repaid at market rates. Some of the funds may also be subsidized or directed for political purposes, rather than economic ends (e.g., Cole 2004, Sapienza 2004). State-owned institutions may also deploy relatively weak monitoring strategies and/or refrain from aggressive collection procedures as part of their mandate to subsidize targeted borrowers or because of the lack of market discipline. In nations with substantial stateowned banking sectors, there may also be significant spillover effects that discourage privately-owned or foreign-owned institutions from SME lending due to a "crowding out” effect from subsidized loans from state-owned institutions.

The empirical findings are generally consistent with unfavorable effects of state ownership. Studies of general performance typically find that individual state-owned banks are relatively inefficient and that large shares of state bank ownership are typically associated with unfavorable macroeconomic consequences and less developed financial and economic systems (e.g., La Porta, Lopez-de-Silanes, and Shleifer 2002, Barth, Caprio, and Levine 2004, Berger, Hasan, and Klapper 2004). Some evidence also suggests that less SME credit is available in nations with large market shares for state-owned banks (e.g., Beck, DemirgucKunt, and Maksimovic 2004a, Berger, Hasan, and Klapper 2004). As well, nonperforming loan ratios at state-owned banks tend to be very high, consistent with lending based on negative net present value projects,

However, in developing nations, foreign-owned banks usually appear to be more profitable and efficient than domestically-owned banks on average (e.g., Claessens, Demirguc-Kunt, and Huizinga 2001, Martinez Peria and Mody 2004), although one study finds roughly equal performance after controlling for a number of different types of governance and governance change (Berger, Clarke, Cull, Klapper, and Udell 2005). 


\section{WPS3795}

weak monitoring, and/or lack of aggressive collection procedures (e.g., Berger, Clarke, Cull, Klapper, and Udell 2005). Studies of the effects of bank privatization in both developed nations and developing nations typically find improvements in performance following the elimination of state ownership (e.g., Clarke, Cull, and Megginson 2005). Similar to the case for foreign-owned institutions, state-owned institutions likely use transactions technologies, but the technologies are generally not identified in the research. ${ }^{11}$

\section{Market competition}

Under the traditional structure-conduct-performance (SCP) hypothesis, market power reduces credit access through any lending technology. Institutions with more market power may charge high rates or fees on loans; have tight credit standards; and/or be less aggressive in finding or serving creditworthy SMEs so managers can take advantage of a "quiet life.” An alternative hypothesis suggests that for one of the lending technologies, relationship lending, market power may be associated with greater access to credit for SMEs. Market power may encourage institutions to invest in lending relationships because the SMEs are less likely to find alternative sources of credit in the future. Market power helps the institution enforce a long-term implicit contract in which the borrower receives a subsidized interest rate in the short term, and then compensates the institution by paying a higher-than-competitive rate in a later period (Sharpe 1990, Petersen and Rajan 1995). However, under a different theoretical model of relationship lending, greater concentration may be associated with less credit availability using this technology (Boot and Thakor 2000).

Thus, economic theory offers conflicting empirical predictions that arise out of different theoretical models about one of the lending technologies, relationship lending. Without separately identifying relationship lending from the other technologies, the empirical predictions for access to credit for SMEs are not clear For example, market power could increase credit availability for some SMEs through a positive effect on relationship lending, but may decrease availability for other SMEs that are more suited to one of the transactions lending technologies. Thus, the effect of market power on overall SME credit availability may go either way, depending on the strength of the different hypotheses and the extent to which the different lending technologies are employed.

A number of studies have looked at measures of SME credit availability, activity, and general

\footnotetext{
${ }^{11}$ There are exceptions to the measured unfavorable effects of state ownership - cases in which state-owned institutions have eliminated government subsidies and appear to operate relatively efficiently and provide significant SME credit (e.g., Townsend and Yaron 2001).
} 


\section{WPS3795}

economic performance and their association with indicators of market power such as concentration and regulatory restrictions on entry and competition. The empirical results are mixed, with some studies finding generally unfavorable effects from market power (e.g., Elsas 2005, Karceski, Ongena, and Smith 2005, Cetorelli and Strahan 2006), and others finding favorable effects (e.g., Petersen and Rajan 1995, Cetorelli and Gambera 2001, Bonaccorsi di Patti and Dell’Ariccia 2004, Cetorelli 2004). ${ }^{12}$

\section{The lending infrastructure}

In this section, we turn our attention to the lending infrastructures of nations and how they affect the feasibility and profitability of using the different lending technologies in SME financing. The lending infrastructure includes the information environment, the legal, judicial and bankruptcy environments, the social environment, and the tax and regulatory environments. All of these elements may affect SME credit availability by influencing the extent to which the different lending technologies may be legally and profitably employed. The final element, the regulatory environment, may also restrict SME credit availability by constraining the financial institution structure.

\section{A. The information environment}

An important aspect of the information environment is the accounting infrastructure. Strong accounting standards and credible independent accounting firms are necessary conditions for informative financial statements, which are key to the financial statement lending technology. These are also important for many components of loan contracting associated with financial statement lending and some of the other lending technologies to a lesser extent. For example, covenants based on financial ratios are not feasible if the ratios calculated from the financial statements are not reliable. Indices of global accounting standards indicate considerable variation across countries both between developed and developing economies and among developed economies (e.g., La Porta, Lopez-de-Silanes, Shleifer, and Vishny 1998).

Another important aspect of the information environment is the sharing of information. Commercial and consumer credit bureaus provide formal organizational mechanisms for the exchange of payment performance data. Credit bureaus have also been found to reduce the cost and time to process loans and the

\footnotetext{
12 Some studies also found that higher measured market power is associated with higher SME loan interest rates (e.g., Hannan 1991, Berger, Rosen, and Udell forthcoming). Although this finding may appear to support the SCP hypothesis, it may also be consistent with the alternative hypothesis of an expansion of relationship lending if relationship loans tend to have higher interest rates on average than transactions loans (which may or may not be the case). Again, much of the difficulty in interpreting the results arises because the lending technologies are not identified.
} 


\section{WPS3795}

level of defaults (Miller 2003). Commercial credit bureau data have also been shown to have power in predicting firm failure beyond financial ratios and other descriptive information about the firm (Kallberg and Udell 2003).

There is considerable variation across countries in terms of the existence of credit bureaus, whether they are publicly- or privately-owned, and the coverage of available information (Miller 2003). Empirical evidence suggests a statistically important link between the existence of third-party information exchanges and credit availability (Pagano and Jappelli 1993, Padilla and Pagano 1997, Love and Mylenko 2003). Specifically, countries with stronger formal information sharing exhibit greater bank lending relative to GNP and country-level credit risk is negatively correlated with measures of formal information sharing (Jappelli and Pagano 2002).

Credit bureau information, where available, is used in conjunction with all of the lending technologies, but it is a driving component of one of the lending technologies, small business credit scoring. It is necessary to have a large database on SME loan performance and the variables used to predict that performance in order to estimate a credible credit scoring model. In the U.S., most banks use external vendors to create the scores, and these vendors rely on a strong information environment in which credit bureaus share consumer and business information and financial institutions share their loan performance data to estimate the model. Some large institutions are also able to generate proprietary models based on their own loan performance experience, but still need information from credit bureaus for the exogenous variables in their models. The strong information environment requirements may help explain why small business credit scoring appears to be used on a widespread basis only in a limited number of developed nations (Miller and Rojas 2004). ${ }^{13}$

The evidence also indicates that access to historical credit information such as business credit bureaus is positively related to the presence of factoring (Klapper 2005). Under certain circumstances factoring can also work well even in weak domestic information environments if the receivables are from obligors located in strong information environments. For example, the receivables of an Estonian firm whose customers are located in Germany may qualify for factoring because the factor can efficiently assess the creditworthiness of

\footnotetext{
${ }^{13}$ There are some efforts to expand the use of this lending technology in developing nations. The World Bank and Fair, Isaac have recently formed a joint venture to determine the feasibility of developing a pooled data small business credit scoring model using data from Brazil, Columbia, and Mexico (Miller and Rojas 2004).
} 


\section{WPS3795}

the German account obligors (Bakker, Klapper, and Udell 2004).

\section{B. The legal, judicial, and bankruptcy environments}

A country's legal, judicial, and bankruptcy environments significantly influence the context in which loan contracting is conducted. The legal environment that affects business lending consists of the commercial laws that specify the property rights associated with a commercial transaction. The judicial and bankruptcy environments determine how well these laws are enforced in commercial disputes and in bankruptcy resolutions. This enforceability, in turn, determines the confidence of contracting parties in financial contracts. Collectively, these features constitute the rule of law as it relates to the extension of credit. Countries differ significantly on this dimension: for some, commercial laws are unambiguous and conducive to commercial transactions and enforcement is predictable; for others commercial law is ambiguous and incomplete, enforcement is problematic, and criminal and racketeering behavior block the creation of new businesses, undermine existing ones, and deter foreign investment (EBRD 2003).

Empirical studies have shown that firms in countries with greater financial development and stronger property rights have increased levels of investment funded by external finance. Firms in countries with weaker financial development and property rights, in contrast, are more likely to rely on potentially less efficient financing from development banks, the government, or informal sources (Beck, Demirguc-Kunt, and Maksimovic 2004b). Smaller firms may be particularly affected. One study found that the effect of financial, legal, and corruption problems consistently constrained the growth of smaller firms more than larger firms in a cross-country analysis (Beck, Demirguc-Kunt, and Maksimovic 2005).

Commercial laws and their enforcement of these laws also affect the ability of banks to deploy specific contracting elements that can be used to address informational opacity problems. Specifically, they can affect the deployment of contracting elements such as covenants, maturity, collateral, and personal commitments that have been shown to mitigate adverse selection and moral hazard problems (e.g., Chan and Kanatas 1985, Berlin and Loeys 1988, Sharpe 1990, Berkowitz and White 2004).

The commercial law on security interests (collateral liens) in a nation, for example, is important in determining the efficacy of collateral in a loan contract, the essential component of the asset-based lending and fixed-asset lending technologies. Key issues include whether a country's commercial law clearly defines how a collateral lien can be perfected, how collateral priority is determined, and how notification of a lien is 


\section{WPS3795}

made. At one extreme are countries such as the U.S. that have a well-developed set of commercial laws that include blanket filings on accounts receivable and inventory (Article 9 of the Uniform Commercial Code) and well-defined electronic registration systems that temporally define lien filings. At the other extreme are countries with, at best, recently implemented commercial law that leaves collateral priority and notification ambiguous. Empirical evidence suggests that the legal efficacy of collateral - in particular, the ability of lenders to seize collateral in the event of default - is associated with increased use of collateral (Qian and Strahan 2005). Although progress is being made on this dimension, many of these countries - such as those in Eastern Europe - are still deficient in key areas such as the scope of assets that can be secured, registration and filing, priority, and enforcement (EBRD 2003). ${ }^{14}$

The efficiency of the judicial and bankruptcy systems are also critical to credit availability. Recent theoretical and empirical research suggests that judicial inefficiency (i.e., high-cost judicial procedures) is associated with decreased access to credit (Jappelli, Pagano, and Bianco 2005). It has also been shown that countries with greater legal procedural formalism - typically associated with civil law countries - take longer to enforce some types of financial contracts (Djankov, La Porta, Lopez-de-Silanes, and Shleifer 2003). The Czech Republic offers an illustration of this problem. The cost of enforcing commercial claims was considerably higher in the Czech Republic than in five other transition economies that have joined the EU, the 15 non-accession EU countries, and the U.S. Pursuing claims in a bankruptcy environment is also quite difficult in this country (World Bank 2003).

The length of time in bankruptcy is a particularly important dimension of efficiency. Also important is the degree to which the application of bankruptcy procedures are associated with adherence to absolute priority. The power of collateral ex ante ultimately depends on the whether the priority rights of secured lenders are upheld in bankruptcy ex post. Details of the laws that are often missed in academic analyses can be extremely important. For example, the rights of secured lenders in the U.S. may at first seem relatively weak because an automatic stay is immediately invoked upon acceptance of a bankruptcy petition by the

\footnotetext{
${ }^{14}$ In many of these countries, lenders cannot file a single lien on all currently existing and future accounts receivable and inventory and instead must identify by invoice number and serial number each receivable and inventory item as it is generated. This effectively renders asset-based lending infeasible.
} 


\section{WPS3795}

bankruptcy court. ${ }^{15}$ The automatic stay prevents all creditors from collecting payments from the bankrupt firm and otherwise enforcing their financial claims. However, under U.S. bankruptcy law, the judge is required to preserve the collateral claim of secured creditors and to give them "adequate protection" if the collateral or its proceeds are denied to the secured lender. That is, the bankruptcy judge is obligated to preserve the value of a secured lender's claim. Moreover, petitions by secured lenders for a waiver from the automatic stay are often filed at the time of the bankruptcy petition and approved by the judge in the case of specific collateral classes, such as accounts receivable (Udell 2004).

The fact that asset-based lending has a significant presence in only 4 nations suggests that these legal, judicial, and bankruptcy environmental conditions represent significant hurdles. Nevertheless, in the countries where asset-based lending exists, it appears to be quite important. In the U.S., for example, the stock of total asset-based loans is about \$300 billion (Commercial Finance Association 2003), compared to the stock of commercial and industrial loans in the U.S. of about $\$ 900$ billion (inclusive of bank asset-based loans).

By the same token that asset-based lending and fixed-asset lending depend on a strong lending infrastructure, a weak lending infrastructure may foster the use of factoring and leasing. This is because under factoring or leasing, the underlying assets - accounts receivable or fixed assets, respectively - are removed from the "borrower" and owned by the "lender," rather than being pledged as collateral. Thus, a lending infrastructure that does not support the use of collateral may encourage the use of these alternatives where the lender owns the asset. Consistent with this, there is evidence that factoring is more important in countries with weak contract enforcement (Klapper 2005). Analyses of transitioning former socialist nations also suggest that weak enforcement may encourage leasing (World Bank 2000, 2002).

Similarly, a weak lending infrastructure may encourage the substitution of relationship lending for some of the transactions lending technologies. The use of implicit contracts in relationship lending may substitute for the explicit contracts of transactions lending when explicit contracts cannot be easily enforced. While this issue has not been examined empirically, there is evidence that legal environments may be associated with relationship-based finance in the context of bank-based versus capital-markets-based financial

\footnotetext{
${ }^{15}$ This was one of the reasons why the U.S. received a low rating in academic analyses of business contracting environments (e.g., La Porta, Lopez-de-Silanes, Shleifer, and Vishny 1998).
} 


\section{WPS3795}

systems. That is, weaker legal systems may have more bank-based rather than capital-markets-based financing (Rajan and Zingales 2003, Ergungor 2004). By extension, this argument may apply to relationship lending versus the transactions technologies.

\section{The social environment}

The social environment may also affect SME credit availability. Evidence suggests that the level of social capital and trust may be important in facilitating the writing and enforcement of financial contracts. Social capital, as proxied by electoral participation, has been found to be significant in explaining regional differences in some measures of entrepreneurial activity, such as number of firms and new firm entry (Guiso, Sapienza, and Zingales 2004). Common language may also help develop mutual trust and facilitate relationship building. It has also been found that cultural differences across countries are associated with differences in the level of investor protection (Stulz and Williamson 2003).

The greatest impact of the social environment is likely on relationship lending because social norms, religion, and culture may have the most effect on the production of soft information and the ability of banks to use this information to forge relationships. The social environment could also affect the production and use of hard information used in the transactions technologies, but likely to a lesser degree.

\section{The tax and regulatory environments}

The tax and regulatory environments may have significant effects on SME credit availability. For example, stamp taxes on factored invoices and certain types of value-added taxes can have negative impacts on factoring. Changes in capital regulations and tougher bank supervision in the U.S. are also often cited as contributing to the reduction in supply of business credit or "credit crunch" in the U.S. in the early 1990s (e.g., Berger and Udell 1994, Peek and Rosengren 1995). The implementation of the Basel II capital requirements may also have an impact in the future by imposing a different implicit tax on SME lending and favoring some lending technologies over others for some financial institutions. For example, large banking organizations may have more favorable capital requirements if they manage SME loans as part of a pool, which may favor some of the transactions technologies over relationship lending (Altman and Sabato 2005, Berger 2006). ${ }^{16}$

\footnotetext{
${ }^{16}$ In the U.S., the largest banks are generally expected to have lower capital requirements on many SME loans, while in other nations, banks of all sizes may have lower requirements on many SME loans. To receive the favorable retail loan categorization, the exposure to the SME must be under $€ 1$ million, and the credit must be managed as a retail exposure as
} 
The regulatory environment may also affect SME credit availability by constraining the financial institution structure. Government policies often affect the entry of different types of financial institutions, their market shares, their abilities to compete, and their corporate governance structure. In many parts of the world, the removal of geographic and product restrictions has resulted in significant consolidation within the banking industry and between banks and other types of financial institutions. In the EU, the single banking license and other parts of the Single Market Programme appeared to spur considerable financial institution consolidation within nations and somewhat less activity across international borders within the EU. In the U.S., removal of state geographic restrictions and the Riegle-Neal Act clearly led to considerable consolidation within the U.S. banking industry, although the Gramm-Leach-Bliley Act did not result in much additional consolidation between banking organizations and other types of financial institutions. However, as discussed in Section 2, the effects of bank size structure on SME credit availability are ambiguous.

Government policies that restrict foreign entry may have large effects on SME credit availability, given the findings that larger market shares for foreign-owned banks are often associated with greater SME credit availability in developing nations. Other research has also found that restrictions on foreign-bank entry may be more strongly linked to bank performance than the market presence of foreign-owned banks (Levine 2003), which may suggest these restrictions have particularly strong effects in limiting competition, with potential consequences for SME customers. As well, restrictions on foreign institutions may limit the efficient use of some of the transactions lending technologies in developing nations, given the likely advantage of these institutions in institutions in collecting and processing hard information.

Finally, government policies with respect to state ownership of financial institutions clearly have important effects on credit availability. State ownership is generally found to have significant negative effects on SME credit availability, with some reversal of these effects after privatization. State-owned institutions likely use transactions lending technologies, but the evidence does not suggest which ones these institutions use or that they have advantages in any of the technologies.

\section{Conclusions}

We offer a more complete conceptual framework for thinking about the research and policy issues

part of a pool or be guaranteed by an individual. For SME loans not classified as retail, there may also be a favorable treatment in some circumstances for loans to firms with under $€ 50$ million in sales. 


\section{WPS3795}

surrounding the availability of credit to SMEs in various circumstances around the globe. We emphasize a causal chain in which the lending technologies provide the crucial link between government policies and financial structures on the one hand, and SME credit availability on the other hand. At the top of the chain, government policies affect a nation's financial institution structure and lending infrastructure. That is, policies help influence the market shares and competitive conditions for large versus small, foreign versus domestic, and state-owned versus private financial institutions (financial institution structure), and the information, legal, judicial, bankruptcy, social, tax, and regulatory environments in which these institutions operate (lending infrastructure). These financial structures then help determine the feasibility and profitability with which the different lending technologies can be deployed to fund SMEs. The financial institution structure affects the use of technologies because the institution types have comparative advantages in different lending technologies. The lending infrastructure affects the legality and profitability of the lending technologies.

At the bottom of the causal chain, the lending technologies have important effects on the access to credit for creditworthy transparent and opaque SMEs. The different technologies - financial statement lending, small business credit scoring, asset-based lending, factoring, fixed-asset lending, leasing, relationship lending, and trade credit - each involves a different combination of primary information source, screening and underwriting policies/procedures, loan contract structure, and monitoring strategies/mechanisms. The choice of lending technology for a specific creditworthy SME depends on the sources of information available for that firm, as well as the adaptability and appropriateness of the various screening, underwriting, contracting, and monitoring techniques dealing with the firm in its environment.

We argue that the framework in the extant research literature is oversimplified and often neglects key elements of this causal chain. In some cases, the literature on SME credit availability has not accounted for or controlled for the presence of alternative lending technologies. A common oversimplification is to treat all transactions lending technologies as a homogeneous group that is not suitable for lending to informationally opaque SMEs. In contrast, we argue that most of the transactions technologies are designed to use hard information other than financial statements to underwrite loans to opaque SMEs. These oversimplifications have often led to misleading conclusions regarding how policies may affect SME credit availability through their impacts on financial institution structure and lending infrastructure. 
We also review much of the extant research on SME credit availability through the lens of this more complete framework, yielding several conclusions. First, the findings argue against drawing simplistic conclusions from the extant research. For example, the finding that large financial institutions have a comparative advantage in transactions lending technologies and comparative disadvantage in relationship lending does not necessarily imply that large institutions are disadvantaged in providing credit to informationally opaque SMEs. On the contrary, some of the transactions lending technologies used by large institutions are well-suited for funding opaque SMEs. Similarly, there is no simple answer to the policy question of whether a sizeable presence of small institutions is needed for overall SME credit availability. A limited amount of research using U.S. data suggests little concern on this issue, but other research suggests that small institution presence may be more important in other nations because differences in financial structures that may limit the use of some lending technologies.

Second, the results make a strong case for taking into account the presence of foreign- and stateowned institutions, as well the presence of large and small institutions and conventional measures of financial institution competition, particularly when analyzing developing nations. All of these elements of financial institution structure may affect SME credit availability through comparative advantages in the different lending technologies. In particular, a greater presence of foreign-owned institutions and a lesser presence of state-owned institutions is likely to be associated with significantly higher SME credit availability in developing nations because foreign-owned institutions appear to have advantages in some of the lending technologies, and state-owned institutions appear to be generally disadvantaged.

Third, our investigation strongly suggests lending infrastructures have important effects on SME credit availability. "Better” lending infrastructures may significantly improve SME credit availability through facilitating the use of the various lending technologies. As examples, better accounting standards may help spur the use of financial statement lending, better commercial laws on security interests may facilitate the use of asset-based lending and fixed-asset lending, and greater sharing of information may help facilitate the use of small business credit scoring, although other parts of the lending infrastructure must also be in place for these technologies to be legally and profitably employed. Similarly, "worse” lending infrastructures may appreciably reduce SME credit availability. This may occur if a restrictive regulatory environment constrains the financial institution structure, preventing some types of financial institutions from capitalizing on their 


\section{WPS3795}

comparative advantages in specific lending technologies. The evidence suggests that these effects may be quite strong, particularly when governments restrict the entry of foreign financial institutions and/or maintain large market shares for state-owned institutions.

For a framework to be useful, it must have clear testable implications, so that the proposed paradigm may be supported or refuted by the data. Our framework postulates how financial structures affect the feasibility and profitability of the different lending technologies, and the effects of these technologies on SME credit availability. This framework has a number of clear testable implications for the links among a nation's financial institution structure, financial infrastructure, lending technologies employed, and SME credit availability.

To the extent that a) differences in financial structures across nations explain a significant portion of the observed variation in the use of different lending technologies; and b) these different technologies explain a significant portion of the observed variance in SME credit availability, the framework would be supported. If differences in the use of the lending technologies are not strongly related to financial institution structure or lending infrastructure, or if the use of the technologies is not strongly associated with SME credit availability, the framework would be refuted.

While comprehensive tests are best, individual elements of the framework may also be tested. The framework predicts specific associations among the individual elements of the financial institution structure, lending infrastructure, technologies, and SME credit availability. For example, the paradigm predicts that the presence of large banks and quality credit bureaus may facilitate the use of small business credit scoring, which, in turn, may be efficiently used to lend to some opaque SMEs. Findings confirming these individual effects would support the framework, while findings of no effects of bank size or credit bureaus on small business credit scoring, or no effect of small business credit scoring on lending to opaque SMEs would tend to refute the framework.

A key issue in testing the framework is the identification of the lending technologies. One solution is for researchers to use the existing data sets to separate out and identify specific lending technologies that often have not been identified in prior research. A small number of prior studies have identified the use of small business credit scoring, asset-based lending, and factoring, but with some effort, more technologies may be identified. A potentially more fruitful long-run future solution would be to structure new and periodically- 
updated data sets to directly identify more of the lending technologies. 


\section{WPS3795}

\section{$\underline{\text { References }}$}

Altman, E.I., Sabato, G., 2005. Effects of the new Basel Capital Accord on bank capital requirements for SMEs. Journal of Financial Services Research 27, forthcoming.

Avery, R.B., Samolyk, K.A., 2004. Bank consolidation and the provision of banking services: Small commercial loans. Journal of Financial Services Research 25: 291-325.

Bakker, Marie H.R., Klapper, L., Udell, G.F., 2004. Financing Small and Medium-size Enterprises with Factoring: Global Growth and its Potential in Eastern Europe. World Bank Monograph, Washington, D.C. http://wbln0018.worldbank.org/html/FinancialSectorWeb.nsf/(attachmentweb)/3342/\$FILE/3342.pdf

Barth, J.R., Caprio, G. Jr., Levine, R., 2004. Bank supervision and regulation: What works best? Journal of Financial Intermediation 13, 205-48.

Beck, T., Demirguc-Kunt, A., Maksimovic, V., 2004a. Bank competition and access to finance: International evidence. Journal of Money, Credit, and Banking 36: 627-648.

Beck, T., Demirguc-Kunt, A., Maksimovic, V., 2004b. Financing patterns around the world: Are small firms different? World Bank working paper.

Beck, T., Demirguc-Kunt, A., Maksimovic, V., 2005. Financial and legal constraints to firm growth: Does firm size matter? Journal of Finance 60, 137-77.

Berger, A.N., 2006. Potential competitive effects of Basel II on banks in SME credit markets in the United States. Journal of Financial Services Research 28.

Berger, A.N., Bonime, S. D., Goldberg, L.G., White, L.J., 2004. The dynamics of market entry: The Effects of Mergers and Acquisitions on Entry in the Banking Industry. Journal of Business 77: 797-834.

Berger, A.N., Clarke, G.R.G., Cull, R., Klapper, L., Udell, G.F., 2005. Corporate governance and bank performance: A joint analysis of the static, selection, and dynamic effects of domestic, foreign, and state ownership. Journal of Banking and Finance 29: 2179-2221.

Berger, A.N., DeYoung, R., Genay, H., Udell, G.F., 2000. The globalization of financial institutions: Evidence from cross-border banking performance. Brookings-Wharton Papers on Financial Services 3: 23-158.

Berger, A.N., Frame, W.S., 2006. Small business credit scoring and credit availability. Journal of Small Business Management 46.

Berger, A.N., Frame, W.S., Miller, N.H., 2005. Credit scoring and the availability, price, and risk of small business credit. Journal of Money, Credit, and Banking 37: 191-222.

Berger, A.N., Goldberg, L.G., White, L.J., 2001. The effects of dynamic changes in bank competition on the supply of small business credit,” European Finance Review 5: 115-139.

Berger, A.N., Hasan, I., Klapper, L.F., 2004. Further evidence on the link between finance and growth: An international analysis of community banking and economic performance, Journal of Financial 


\section{WPS3795}

Services Research 25: 169-202.

Berger, A.N., Klapper, L.F., Udell, G.F., 2001. The ability of banks to lend to informationally opaque small businesses. Journal of Banking and Finance 25: 2127-2167.

Berger, A.N., Miller, N.H., Petersen, M.A., Rajan, R.G., Stein, J.C., 2005. Does function follow organizational form? Evidence from the lending practices of large and small banks, Journal of Financial Economics 76, 237-269.

Berger, A.N., Rosen, R.J., Udell, G.F., forthcoming. Does market size structure affect competition? The case of small business lending. Journal of Banking and Finance.

Berger, A.N., Saunders, A., Scalise, J.M., Udell, G.F., 1998. The effects of bank mergers and acquisitions on small business lending. Journal of Financial Economics 50: 187-229.

Berger, A.N., Udell, G.F., 1994. Did risk-based capital allocate bank credit and cause a 'credit crunch' in the U.S.? Journal of Money, Credit and Banking 26: 585-628.

Berger, A.N., Udell, G.F., 1995. Relationship lending and lines of credit in small firm finance. Journal of Business 68: 351-382.

Berger, A.N., Udell, G.F., 2002. Small business credit availability and relationship lending: The importance of bank organisational structure. Economic Journal 112: F32-F53.

Berkowitz, J., White, M.J., 2004. Bankruptcy and small firms' access to credit. The Rand Journal of Economics 35: 69-84.

Berlin, M., Loeys, J., 1988. Bond covenants and delegated monitoring, Journal of Finance 43, 397-412.

Bonaccorsi di Patti, E., Dell’Ariccia, G., 2004. Bank competition and firm creation. Journal of Money, Credit, and Banking 36: 225-251.

Buch, C.M., 2003. Information versus regulation: What drives the international activities of commercial banks? Journal of Money Credit and Banking 35: 851-869.

Burkart, M., Ellingsen, T., 2004. In-kind finance. A theory of trade credit. American Economic Review 94, 569-590.

Burkart, M., Ellingsen, T., Giannetti, M., 2005. What you sell is what you lend? Explaining trade credit contracts. Stockholm School of Economics working paper.

Carey, M., Post, M., Sharpe, S.A., 1998. Does corporate lending by banks and finance companies differ? Evidence on specialization in private debt contracting, Journal of Finance 53, 845-878.

Cetorelli, N., 2004. Bank concentration and competition in Europe. Journal of Money, Credit, and Banking 36: 543-558.

Cetorelli, N., Gambera, M., 2001. Banking market structure, financial dependence and growth: International evidence from industry data. Journal of Finance 56: 617-648. 


\section{WPS3795}

Cetorelli, N., Strahan, P.E., 2006. Finance as a barrier to entry: Bank competition and industry structure in local U.S. markets. Journal of Finance 61.

Chan, Y.-S., Kanatas, G., 1985. Asymmetric valuation and the role of collateral in loan agreements, Journal of Money, Credit and Banking 17, 85-95.

Chan, K., Chan, L.K.C., Jegadeesh, N., Lakonishok, J., 2006. Earnings quality and stock returns. Journal of Business 79.

Chemmanur, T., Yan, A., 2000. Equilibrium leasing contracts under double-sided asymmetric information. Boston College working paper.

Claessens, S., Demirguc-Kunt, A., Huizinga, H., 2001. How does foreign entry affect the domestic banking market? Journal of Banking and Finance 25: 891-911.

Clarke, G., Cull, R., Martinez Peria, M.S., Sanchez, S.M., 2005. Bank lending to small businesses in Latin America: Does bank origin matter? Journal of Money, Credit, and Banking 37: 83-118.

Clarke, G., Cull, R. and Megginson, W.L., editors, 2005. Bank Privatization. Special Issue of Journal of Banking and Finance 29.

Cole, R. A., Goldberg, L.G., White, L.J., 2004. Cookie-cutter versus character: The micro structure of small business lending by large and small banks. Journal of Financial and Quantitative Analysis 39: 227251.

Cole, S., 2004. Fixing market failures or fixing elections? Agricultural credit in India, mimeo. MIT.

Commercial Finance Association, 2003. Marketing Survey for the Asset-Based Financial Services Industry.

Cook, L., 1999. Trade credit and bank finance: Financing small firms in Russia, Journal of Business Venturing 14, 493-518.

Cunat, V.M., 2003. Trade credit: Suppliers as debt collectors and insurance providers. Universitat Pampeu Fabra working paper.

Degryse, H., Cayseele, P.V., 2000, Relationship lending within a bank-based system: Evidence from European small business data. Journal of Financial Intermediation 9, 90-109.

Demirguc-Kunt, A., Maksimovic, V., 1998. Law, finance, and firm growth. Journal of Finance 53, 21072137.

DeYoung, R., Nolle, D.E., 1996. Foreign-owned banks in the U.S.: Earning market share or buying it? Journal of Money, Credit, and Banking 28: 622-636.

Demirguc-Kunt, A., Maksimovic, V., 2002. Firms as financial intermediaries: Evidence from trade credit data, University of Maryland working paper.

Djankov, S., La Porta, R., Lopez-de-Silanes, F., Shleifer, A., 2003. Courts, Quarterly Journal of Economics 118: 453-516. 


\section{WPS3795}

Elsas, R, 2005. Empirical determinants of relationship lending, Journal of Financial Intermediation 14, 32-57.

Ergungor, O. E., 2004. Market- vs. bank-based financial systems: Do rights and regulations really matter? Journal of Banking and Finance 28: 2869-2887.

European Bank for Reconstruction and Development (EBRD), 2003. Transition Report 2003.

Frame, W. S., Padhi, M., Woosley, L., 2004. Credit scoring and the availability of small business credit in low- and moderate income areas. Financial Review 39: 34-54.

Frank, M.Z., Maksimovic, V., 2003. Trade credit, collateral and adverse selection, University of Maryland working paper.

Giannetti, M., Ongena, S., 2005. Financial integration and entrepreneurial activity: Evidence from foreign bank entry in emerging markets. European Corporate Governance Institute working paper 91/2005.

Gilligan, T.W., 2004. Lemons and leases in the used business aircraft market. Journal of Political Economy 112, $1157-1180$.

Goldberg, L.G., Saunders, A., 1981. The determinants of foreign banking activity in the United States. Journal of Banking and Finance 5, 17-32.

Graham, J.R., Lemmon, M.L., Shallheim, J.S., 1998. Debt, leases, taxes, and the endogeneity of corporate tax status. Journal of Finance 53, 131-162.

Guiso, L., Sapienza, P., Zingales, L., 2004. Does local financial development matter? Quarterly Journal of Economics 119: 929-969.

Hannan, T.H., 1991. Bank commercial loan markets and the role of market structure: Evidence from surveys of commercial lending. Journal of Banking and Finance 15: 133-49.

Haynes, G.W., Ou, C., Berney, R., 1999. Small business borrowing from large and small banks, in Business Access to Capital and Credit, edited by Blanton, J.L., Williams, A., Rhine, S.L.W., A Federal Reserve System Research Conference, 287-327.

Hendel, I., Lizzeri, A., 2002. The role of leasing under adverse selection. Journal of Political Economy 110, 113-142.

Jappelli, T., Pagano, M., 2002. Information sharing, lending and defaults: Cross-country evidence, Journal of Banking and Finance 26: 2017-2045.

Jappelli, T., Pagano, M., Bianco, M., 2005. Courts and banks: Effects of judicial enforcement on credit markets. Journal of Money, Credit and Banking 37: 223-244.

Jayaratne, J., Wolken, J.D., 1999. How important are small banks to small business lending? New evidence from a survey of small firms. Journal of Banking and Finance 23: 427-58.

Kallberg, J., Udell, G. F., 2003. The value of private sector credit information sharing: The U.S. case, Journal of Banking and Finance 27 449-469. 


\section{WPS3795}

Karceski, J., Ongena, S., Smith, D., 2005. The impact of bank consolidation on commercial borrower welfare, Journal of Finance 60.

Klapper, L., 1998. Short-term collateralization: Theory and evidence, New York University working paper.

Klapper, L., 2005. The role of factoring for financing small and medium enterprises, World Bank working paper.

La Porta, R., Lopez-de-Silanes, F., Shleifer, A., Vishny, R.W., 1998. Law and finance. Journal of Political Economy 106: 1113-1155.

La Porta, R., Lopez-de-Silanes, F., Shleifer, A., 2002. Government ownership of banks. Journal of Finance 57: 265-301.

Levine, R., 2003. Denying foreign bank entry: Implications for bank interest margins. University of Minnesota mimeo.

Love, I., Mylenko, N., 2003. Credit reporting and financing constraints, World Bank working paper.

Martinez Peria, M.S., Mody, A., 2004. How foreign participation and market concentration impact bank spreads: Evidence from Latin America. Journal of Money, Credit, and Banking 36: 511-537.

Mester, L.J., Nakamura, L.I., Renault, M., 2004. Checking accounts and bank monitoring, Federal Reserve Bank of Philadelphia working paper.

Mian, A., forthcoming. Distance constraints: The limits of foreign lending in poor economies, Journal of Finance.

Miller, M., 2003. Credit Reporting Systems and the International Economy, Cambridge: MIT Press.

Miller, M., Rojas, D., 2004. Improving access to credit for SMEs: An empirical analysis of the viability of pooled data SME credit scoring models in Brazil, Colombia, and Mexico, World Bank working paper.

Nakamura, L.I., 1993. Commercial bank information: Implications for the structure of banking, in Klausner, M.D., White, L.J. (Eds.), Structural Change in Banking, Homewood, Illinois: Business One Irwin, 131-160.

Padilla, A.J., Pagano, M., 1999. Sharing default information as a borrower discipline device, University of Salerno: CSEF Working Paper n. 21.

Pagano, M. and Jappelli, T., 1993. Information sharing in credit markets, Journal of Finance 43, 1693-1718.

Peek, J., Rosengren, E.S., 1995. Bank regulation and the credit crunch. Journal of Banking and Finance 19: 679-92.

Petersen, M.A. and Rajan, R.G., 1994. The benefits of firm-creditor relationships: Evidence from small business data, Journal of Finance 49, 3-37.

Petersen, M.A., Rajan, R.G., 1995. The effect of credit market competition on lending relationship. Quarterly 


\section{WPS3795}

Journal of Economics 110: 407-443.

Petersen, M.A. and Rajan, R.G., 1997. Trade credit: Theories and evidence, Review of Financial Studies 10, 661-669.

Qian, J., Strahan, P.E., 2005. How law and institutions shape financial contracts: The case of bank loans, National Bureau of Economic Research working paper 11052.

Rajan, R.G., Zingales, L., 2003. The great reversals: the politics of financial development in the twentieth century, Journal of Financial Economics 69, 5-50.

Robb, A.M., 2002. Small business financing: Differences between young and old firms. Journal of Entrepreneurial Finance and Business Ventures 7: 45-65.

Sapienza, P., 2004. The effects of government ownership on bank lending. Journal of Financial Economics 74: 357-384.

Scott, J.A., 2004. Small business and value of community financial institutions. Journal of Financial Services Research 25: 207-230.

Sharpe, S.A., 1990. Asymmetric information, bank lending, and implicit contracts: A stylized model of customer relationships. Journal of Finance 45: 1069-87.

Stein, J.C., 2002. Information production and capital allocation: Decentralized vs. hierarchical firms,” Journal of Finance 57, 1891-1921.

Stulz, R.M., Williamson, R., 2003. Culture, openness and finance. Journal of Financial Economics 70: 313349.

Townsend, R.M., Yaron, J., 2001. The credit risk-contingency system of an Asian development bank, Economic Perspectives, Federal Reserve Bank of Chicago, 31-48.

Udell, G.F., 2004. Asset-Based Finance, New York: The Commercial Finance Association.

United Nations UNCITRAL website, www.uncitral.org.

Williamson, O., 1988. Corporate finance and corporate governance. Journal of Finance 43: 567-91.

World Bank, 2000. Development of Financial Leasing in Lithuania, December.

World Bank, 2002. Lithuania, Insolvency and Creditor Rights System, February.

World Bank, 2003. Czech Republic, Policy note: Insolvency and Creditor Rights System, fourth draft, October. 